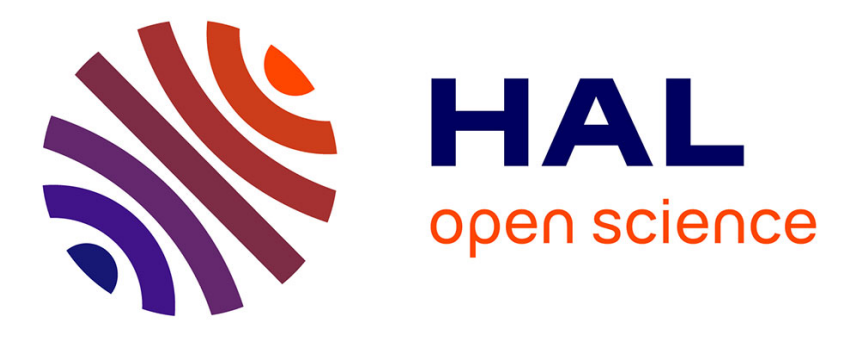

\title{
Deoxynivalenol inhibits the expression of trefoil factors (TFF) by intestinal human and porcine goblet cells
} Fabien Graziani, Philippe Pinton, Hamza Olleik, Ange Pujol, Cendrine

Nicoletti, Mehdi Sicre, Nathalie Quinson, El Hassan Ajandouz, Josette Perrier, Eric Di Pasquale, et al.

\section{To cite this version:}

Fabien Graziani, Philippe Pinton, Hamza Olleik, Ange Pujol, Cendrine Nicoletti, et al.. Deoxynivalenol inhibits the expression of trefoil factors (TFF) by intestinal human and porcine goblet cells. Archives of Toxicology, 2019, 93 (4), pp.1039-1049. 10.1007/s00204-019-02425-6 . hal-02626403

\section{HAL Id: hal-02626403 https://hal.inrae.fr/hal-02626403}

Submitted on 15 Dec 2021

HAL is a multi-disciplinary open access archive for the deposit and dissemination of scientific research documents, whether they are published or not. The documents may come from teaching and research institutions in France or abroad, or from public or private research centers.
L'archive ouverte pluridisciplinaire HAL, est destinée au dépôt et à la diffusion de documents scientifiques de niveau recherche, publiés ou non, émanant des établissements d'enseignement et de recherche français ou étrangers, des laboratoires publics ou privés. 


\title{
Deoxynivalenol inhibits the expression of trefoil factors (TFF) by intestinal human and porcine goblet cells.
}

Fabien Graziani ${ }^{1, \pi}$, Philippe Pinton ${ }^{2, \pi}$, Hamza Olleik $^{1}$, Ange Pujol ${ }^{1}$, Cendrine Nicoletti ${ }^{1}$, Mehdi Sicre ${ }^{3}$, Nathalie Quinson ${ }^{1}$, El Hassan Ajandouz ${ }^{1}$, Josette Perrier ${ }^{1}$, Eric Di Pasquale ${ }^{4}$, Isabelle P. Oswald², \#, Marc Maresca, \#.

${ }^{1}$ Aix Marseille Univ, CNRS, Centrale Marseille, iSm2, UMR 7313,13397 Marseille, France

${ }^{2}$ Toxalim (Research Centre in Food Toxicology), Université de Toulouse, INRA, ENVT, INP-Purpan, UPS, 31027 Toulouse, France

${ }^{3}$ Aix-Marseille Université, CNRS, LNC UMR 7291, Marseille, France

${ }^{4}$ Aix-Marseille Univ, CNRS, INP, Inst Neurophysiopathol, Marseille, France

I F.G and P.P contributed equally to this work

\# To whom correspondence should be addressed. Dr IP Oswald, Isabelle.Oswald@inra.fr, Phone: +33 582066366 or Dr M. Maresca, m.maresca@univ-amu.fr. Phone: +33 4912882 54. Fax: +33 49128 8440

\begin{abstract}
Trefoil factors (TFFs) are bioactive peptides expressed by several epithelia, including the intestine, where they regulate key functions such as tissue regeneration, barrier function and inflammation. Although food-associated mycotoxins, including deoxynivalenol (DON), are known to impact many intestinal functions, modulation of TFFs during mycotoxicosis has never been investigated. Here, we analyzed the effect of DON on TFFs expression using both human goblet cells (HT29-16E cells) and porcine intestinal explants. Results showed that very low doses of DON (nanomolar range) inhibit the secretion of TFFs by human goblet cells (IC 50 of 361,387 and 243 nM for TFF1, 2 and 3 , respectively) and prevent wound healing. RT-qPCR analysis demonstrated that the inhibitory effect of DON is related to a suppression of TFFs mRNA expression. Experiments conducted on porcine intestinal explants confirmed the results obtained on cells. Finally, the use of specific inhibitors of signal pathways demonstrated that DON-mediated suppression of TFFs expression mainly involved Protein Kinase $\mathrm{R}$ and the MAP kinases (MAPK) p38 and ERK1/2. Taken together, our results show for the first time that at very low doses, DON suppresses the expression and production of intestinal TFFs and alters wound healing. Given the critical role of TFFs in tissue repair, our results suggest that DON-mediated suppression of TFFs contributes to the alterations of intestinal integrity the caused by this toxin.
\end{abstract}

Keywords Deoxynivalenol · Mycotoxin · Goblet cells · TFF1 - TFF2 - TFF3

\section{Introduction}

The epithelial cells covering the intestinal surface is a renewing tissue, constituting a selective barrier that allows the absorption of nutrients and limits the entry of noxious molecules and micro-organisms. The functional integrity of this barrier relies on the coordinated regulation of different process including the production of mucus, the establishment of intercellular tight junctions, and the epithelial self- renewal. Goblet cells play a critical role in barrier function since these particular intestinal epithelial cells, not only pro- duce mucins, but also secrete factors regulating the epithelial renewal and healing (Kim and $\mathrm{Ho}$ 2010). Indeed, the intestinal epithelium is considered as the most rapidly proliferating tissue of the body with a complete turnover every $24-96 \mathrm{~h}$, the epithelial renewal taking place through a combination of cell division, cell migration (also called restitution) and surface shedding (Potten et al. 1992; Taupin and Podolsky 2003; Sturm and Dignass 2008). Various signal molecules participate in epithelial renewal. Although secreted growth factors, such as epidermal growth factor (EGF), hepatocyte growth factor (HGF) and transforming growth factor (TGF) play a role through the stimulation of cell division, the trefoil factors (TFFs) play an critical role through their ability to stimulate cell migration/restitution (Taupin and Podolsky 2003; Playford et al. 2004; Hoffmann 2005). In fact, TFFs do not promote or regulate cell proliferation/division but rather stimulate cell migration that is essential during epithelial restitution (Dignass et al. 1994). The major role of TFFs in tissue repair has been elegantly demonstrated using knock- out mice, the deficiency in TFFs causing an ineffective intestinal repair response after intestinal injuries by chemicals, radiations or hypoxia (Mashimo et al. 1996; Furuta et al. 2001; Beck et al. 2004). In addition to their major role in intestinal healing, TFFs have also additional regulatory activities on intestinal immunity and inflammation (Kjellev 2009; Hoffmann 2009). At present, three members of the trefoil factor family (i.e., TFF1, 2 and 3 ) have been charac- terized in mammals. They are small peptides (6.5-12 kDa) having in common a trefoil domain (38 or 39 amino acids) stabilized by three intramolecular 
disulfide bridges. TFFs are expressed by various organs of the body, but they are mostly secreted by mucin-producing cells of epithelia, such as intestinal goblet cells (Madsen et al. 2007; Kjellev 2009).

In relation to their critical role in intestinal healing and to their ability to modulate intestinal immunity and inflammation, alterations of TFFs expression was associated with inflammatory bowel diseases (Playford et al. 2004; Sturm and Dignass 2008; Aamann et al. 2014). TFFs levels vary significantly in the case of some digestive tract cancers, and could potential serve for early detection of these diseases (Chaiyarit et al. 2015; Xiao et al. 2015; Xie et al. 2017). However, the effect of exposure to toxins on their expression is still uncharacterized.

Mycotoxins are fungal secondary metabolites contaminat- ing the food chain and affecting animal and human health (Bennett et al. 2003; Wu et al. 2014). Among the various mycotoxins, deoxynivalenol (DON) is one of the most stud- ied due to its known deleterious effects and high prevalence (Maresca 2013; Payros et al. 2016). As other trichothecenes, DON is a small sesquiterpenoid with an epoxide group at position 12-13 critical for its biological effects (Maresca 2013). Although it was first thought that this epoxide group was reactive and creates a covalent bound between DON and the ribosomes, it has been recently demonstrated that it is critical for DON to adopt an appropriate conformation able to interact with ribosomes (Pierron et al. 2016a; Dellafiora et al. 2018). This leads to the so-called ribosome stress response characterized by the activation of various protein kinases (including the Protein Kinase $R(P K R)$ and the MAP kinases p38 and ERK1/2) and eventually causing the modulation of gene expression, the inhibition of protein

synthesis and the cell death depending of the dose and time of exposure (Lucioli et al. 2013; Maresca 2013). DON is known to alter the functions of various tissues and organs such as the immune system, the brain and the intestine (Pestka 2010; Razafimanjato et al. 2011; Alassane-Kpembi et al. 2017). At the gut level, DON is able to affect numerous processes, including the barrier function, the absorption of nutrients, the production of mucus and the intestinal immu- nity (Maresca 2013; Pinton and Oswald 2014; Robert et al. 2017). No data are however available at present regarding the potential effect of DON on the intestinal expression of TFFs by goblet cells. We recently used a validated in vitro model of human goblet cells, i.e., the HT29-16E cells, to demonstrate that DON inhibits mucins expression through modulation of the resistin-like molecule $\beta$ (RELM $\beta$ ) (Pin- ton et al. 2015). In the present study, HT29-16E cells and porcine intestinal explants were used to study the impact of DON on TFFs expression by human and animal goblet cells. Results demonstrated that low doses (i.e., nanomolar range) of DON decrease the expression and secretion of TFFs by goblet cells contributing to the intestinal alterations and lesions caused by this toxin.

\section{Materials and methods}

Cell culture

HT29-16E cells (generous gift from Prof Christian Laboisse) and Caco-2 cells (ATCC HTB-37) were maintained in Dul- becco's modified essential medium (DMEM) supplemented with $10 \%$ fetal calf serum (FCS), 1\% I-glutamine and 1\% antibiotics (all from Invitrogen) and maintained in a 5\% CO2 incubator at $37^{\circ} \mathrm{C}$. For studying DON effects, HT29-16E cells were seeded at an initial density of 250,000 cells per $\mathrm{cm}^{2}$ onto 12 or 96 well plates and let to differentiate for 10-14 days, preliminary experiments showing that expres- sion and secretion of TFF were optimal at that time.

Preparation of jejunal explants

Six castrated male piglets, acquired just after weaning, were used to prepare intestinal explants. All experiments were conducted under the approval of the French Ministry of Higher Education and Research (decision no. \#6303_2016080314392462, February 2nd 2017). Animals were slaughtered by electronarcosis before exsanguination. The jejunum was rapidly excised and processed as previously described (Alassane-Kpembi et al. 2017; García et al. 2018). Briefly, biopsy punches were laid on sponges and incubated for 8 or $12 \mathrm{~h}$ in Williams medium (Sigma) supplemented with penicillin, streptomycin, gentamicin and 10\% fetal calf serum (Eurobio, Courtaboeuf, France), $4.5 \mathrm{~g} / \mathrm{l}$ of D-glucose and $30 \mathrm{mM}$ of amino acid (Ala/Glu) (Sigma) in presence of $10 \mu \mathrm{M}$ of DON at $39{ }^{\circ} \mathrm{C}$, under a $\mathrm{CO}_{2}$ controlled atmosphere with orbital shaking before they were used for gene expression assessment.

\section{Mycotoxin treatment}

DON (from Romer Lab) stock solutions was prepared in anhydrous ethanol and stored at $-20^{\circ} \mathrm{C}$. Serial dilutions of DON were prepared in anhydrous ethanol allowing the addition of similar volume of vehicle in all experiments. HT29-16E cells were treated with the indicated concentrations of DON or equivalent volume of ethanol (for untreated cells) (1\% final, volume/volume) in DMEM without FCS and without antibiotics. 
Analysis of TFFs secretion by ELISA

HT29-16E cells seeded onto 12-well plates were treated or not with DON. After exposure to toxin, cell supernatants were collected, centrifuged at $1200 \mathrm{rpm}$ for $5 \mathrm{~min}$ at $4{ }^{\circ} \mathrm{C}$ and stored at $-80{ }^{\circ} \mathrm{C}$ for later use. For ELISA analysis, $200 \mu \mathrm{l}$ of HT29-16E cell culture supernatants or of increasing concentrations of pure TFFs standards (recombinant human TFF1, 2 and 3, Peprotech) diluted in DMEM were added onto 96-well plates (MaxiSorp from Nunc) and incubated overnight at $4{ }^{\circ} \mathrm{C}$. Plates were washed three times with wash buffer (PBS plus $0.025 \%$ Tween-20). Wells were then saturated with PBS containing $2 \%$ BSA. Primary antibodies against human TFF1 (sc-28925), TFF2 (sc-23558) or TFF3 (sc-81467) (all from Santa Cruz, 1:100 dilution) were added for $1 \mathrm{~h}$ at room temperature. Wells were washed three times and horseradish (HRP)-conjugated secondary antibodies (1:10,000) (Jackson Immunoresearch) were added for $1 \mathrm{~h}$ at room temperature. After six washes, HRP substrate (Fast OPD from SigmaAldrich) was added. After 30 min of color development, reaction was stopped with concentrated $\mathrm{H}_{2} \mathrm{SO}_{4}$ and the optical density was finally measured at $490 \mathrm{~nm}$. TFFs concentrations in samples were determined using the standard curves obtained using pure recombinant human TFF1, 2 or 3 (from Peprotech).

\section{Measurement of the cell viability}

Integrity and viability of HT29-16E cells were evaluated using lactate dehydrogenase (LDH) and MTT assays, respec- tively (Razafimanjato et al. 2010, 2011; Pinton et al. 2015). For the LDH assay, HT29$16 \mathrm{E}$ cells seeded onto 12-well plates were treated with increasing concentrations of DON for various times. Then, $50 \mu \mathrm{l}$ of culture supernatants were collected and added to $250 \mu \mathrm{l}$ of reaction buffer containing Tris- $\mathrm{HCl}(86 \mathrm{mM} ; \mathrm{pH}$ 9.3), $\mathrm{KCl}(172 \mathrm{mM})$, L-lactic acid $(56 \mathrm{mM})$ and NAD (6.88 mM) in 96well microplates. OD

at $340 \mathrm{~nm}$ was measured $30 \mathrm{~s}$ after culture supernatants were added to wells giving the initial measure. OD340 nm was then measured after 10 min of incubation at $37^{\circ} \mathrm{C}$, variation of OD being linear over this time period (data not shown). Percentage of released LDH was finally calculated using cells lysed with Triton X-100 ( $1 \%$ final concentration) as $100 \%$ of release. The MTT assay was performed on HT29-16E cells seeded onto 96-well plates as previously described (Razafimanjato et al. 2010, 2011; Pinton et al. 2015).

Wound-healing assay

The effect of goblet cells on enterocyte migration was studied using Caco- 2 cells as model of enterocytes. Caco-2 cells were seeded at an initial density of 250,000 cells per $\mathrm{cm}^{2}$ onto culture devices specifically designed for wound-healing assays (iBdi). After 3-4 days of growth, when cell confluence was reached, cell monolayer was washed three times with DMEM medium without FCS and antibiotics. The cen- tral detachable plastic part of the device was then removed according to manufacturer's instructions to create a regular wound of $500 \mathrm{~nm}$ of length across the Caco-2 cell monolayer. Wells were then filled with conditioned medium collected from confluent HT29-16E cells seeded onto 12-well plates and treated or not with DON at $10 \mu \mathrm{M}$ in DMEM without FCS for $48 \mathrm{~h}$. To avoid artifacts due to the presence of DON, DON was eliminated from HT29-16E cell culture supernatants using $1 \mathrm{kDa}$ Centricon devices before being added onto Caco-2 cells. Briefly, culture supernatants were passed through the Centricon tubes by centrifugation accordingly to manufacturer's protocol. Retained conditioned supernatants (MW $>1 \mathrm{kDa}$ ) were washed three times with $0.5 \mathrm{ml}$ of DMEM without FCS. After the last wash, retained conditioned supernatants were collected, diluted with DMEM without FCS to the volume initially filtered and added onto Caco-2 cell monolayers. The absence of DON was confirmed using ELISA kit (AgraQuant, Romer lab). DMEM containing 10\% FCS and DMEM without FCS were, respectively, used as positive and negative control of wound healing. Cells were returned at $37^{\circ} \mathrm{C}$ in the $5 \% \mathrm{CO}_{2}$ incubator. After 24 or $48 \mathrm{~h}$ of incubation, Caco-2 cell monolayer was observed and pictures were taken using photonic micro- scope device (Floid cell imaging station, Life Technologies). Tissue repair was evaluated through the measurement of the length and the area of the wound over the time.

\section{Quantification of TFFs mRNA}

Total mRNA from HT29-16E cells or porcine intestinal explants were extracted and quantified as previously described (Pinton et al. 2012, 2015; Graziani et al. 2015; Gourbeyre et al. 2015). Primers used for mRNA quantifiation were selected using Universal Probe Library Assay Design Center (Roche applied science) when available or designed at home. Their sequences are reported in Tables 1 and 2. TFFs mRNA levels were normalized to house-keep- ing genes, i.e., GAPDH and cyclophilin A, ribosomal protein L32 or $\beta-2$ microglobulin, for HT29-16E cells and porcine explants, respectively. The relative quantification of TFFs mRNA levels was performed using the comparative $\Delta \Delta \mathrm{Ct}$ method (Livak and Schmittgen 2001). 
Identification of the signal pathways involved in DON effect

DON is known to activate signal pathways such as the Pro- tein Kinase $R(P K R)$ and the mitogenactivated protein kinases (MAP kinases) p38 and ERK1/2 (Pinton et al. 2012; Lucioli et al. 2013; Maresca 2013). To test the involvement of such signal pathways in DON effect on TFF expression in HT29-16E cells, specific inhibitors were added 30 min prior DON treatment $(10 \mu \mathrm{M})$. Inhibitors used were adenine (specific PKR inhibitor, 2 mM), SB 203580 (specific p38 inhibitor, $20 \mu \mathrm{M}$ ), PD 98059 (specific ERK1/2 inhibitor, $50 \mu \mathrm{M}$ ) (all from Tocris), preliminary data having shown that inhibitors at these doses have no effect on TFFs expression (data not shown). After $48 \mathrm{~h}$ incubation, TFFs expression was then analyzed using RT-qPCR as explained above.

\section{Statistical analysis}

All experiments were conducted in triplicate. IC50 were calculated using GraphPad® Prism 7 software. $t$ test and two-way ANOVA analyses were used to address the signifi- cant differences between mean values with significance set at $p<0.05$.

\section{Results}

DON inhibits the secretion of TFFs by human intestinal goblet cells

The impact of DON on TFFs secretion was first studied on HT29-16E cells, a well-characterized model of human goblet cells. Dose-dependent effect of DON on TFFs secretion was evaluated after $48 \mathrm{~h}$ exposure of HT29-16E cells to increasing doses of toxin (Fig. 1). Results showed that DON is able to suppress the secretion of TFFs by human goblet cells, with a statistically significant effect starting at 1 $\mu \mathrm{M}(77.2 \pm 6.3,87.5 \pm 11.2$ and $92.4 \pm 8.8 \%$ inhibition for TFF1, 2 and 3 , respectively $(p<0.01))$ and half-inhibitory concentration $\left(\mathrm{IC}_{50}\right.$ ) values of $0.361 \pm 0.087,0.387 \pm 0.131$ and $0.243 \pm 0.072 \mu \mathrm{M}$ for TFF1, 2 and 3, respectively. Importantly, measurement of the effect of 48-h exposure to DON on the viability of HT29-16E cells by LDH and MTT assays demonstrated that cytotoxicity only appears at doses of DON higher than $25 \mu \mathrm{M}$, with an $\mathrm{IC}_{50}$ on cell viability of $79 \pm 27$ and $88 \pm 12 \mu \mathrm{M}$ for LDH and MTT assay, respectively (Fig. 2), demonstrating that the inhibitory effect of DON on TFFs secretion is specific and not due to general toxicity.

Based on the major role of TFFs in tissue repair, inhibitory effect of DON on TFFs secretion was further studied using wound-healing assay (Figs. 3,4 ). The ability of conditioned media originating from human goblet cells (HT29-16E cells cultured in DMEM-FCS) exposed or not to DON (10 $\mu \mathrm{M}$ for $48 \mathrm{~h}$ ) to stimulate wound healing of human enterocytes (Caco-2 cells) was tested. Conditioned medium obtained from untreated HT29-16E cells was able to stimulate wound healing similarly to the positive control medium (DMEM + FCS) (decrease in the wound distance of $68.3 \pm 11.4$ and $98.7 \pm 6.1 \%$ or $50.2 \pm 9.8$ and $88.2 \pm 13.1 \%$ and decrease in the wound area of $74.1 \pm 15.9$ and $96.2 \pm 22.6 \%$ or $45.8 \pm 13.1$ and $89.3 \pm 18.1 \%$ at 24 and $48 \mathrm{~h}$ for DMEM + FCS or HT29-16E conditioned medium, respectively) confirming the ability of HT29-16E supernatant to cause cell migration and wound healing. By contrast, conditioned medium obtained from HT29-16E cells treated with DON was unable to induce cell migration and wound healing giving similar results to negative control (DMEM-FCS) (decrease in the wound distance of $14.1 \pm 2.9$ and $45.6 \pm 12.8 \%$ or $17.1 \pm 15.6$ and $40.9 \pm 24.1 \%$ and decrease in the wound area of $11.5 \pm 13.8$ and $49.1 \pm 17.3 \%$ or $22.4 \pm 19.1$ and $31.5 \pm 26.1 \%$ at 24 and $48 \mathrm{~h}$ for DMEM-FCS or DON-treated HT29-16E conditioned medium, respectively). Quantification of TFF secretion by ELISA confirmed that DON-treated HT29-16E conditioned medium contained significantly less TFF proteins compared to HT29-16E conditioned medium $(9.7 \pm 0.6,36.1 \pm 2.8$ and $33.4 \pm 1.8 \mathrm{ng} / \mathrm{ml}$ versus $1.2 \pm$ $0.2,2.3 \pm 0.4$ and $2.1 \pm 0.3 \mathrm{ng} / \mathrm{ml}$ for TFF1, TFF2 and TFF3 in HT29-16E-conditioned medium and DON-treated HT29-16E-conditioned medium, respectively).

DON inhibits the mRNA expression of TFFs by human and pig goblet cells

Since DON inhibits TFFs secretion, study was conducted to evaluate if this inhibitory effect was due to an inhibition of TFFs mRNA expression. Time-dependent effect of DON on TFFs mRNA expression in HT-29-16E cells was first studied (Fig. 5a). Results showed that DON at $10 \mu \mathrm{M}$ caused a biphasic effect on TFF1, 2 and 3 mRNA expression. An initial increase in mRNA expression was observed after exposure of $3 \mathrm{~h}$ with $55 \pm 5,146 \pm 7$ and $62 \pm 14 \%$ increase for TFF1, TFF2 and TFF3 mRNA, respectively. This initial stimulation was followed by a progressive decrease in the expression of TFFs mRNA over time, leading to nearly complete suppression after exposure of $48 \mathrm{~h}$ (i.e., $93 \pm 4,99 \pm 0.5$ and $92 \pm 1 \%$ of inhibition for TFF1, TFF2 and TFF3, respectively).

Next, dose-dependent study of the effect of DON on TFFs mRNA expression was performed after 48-h exposure of human goblet cells to increasing doses of DON. Results showed that DON caused a dosedependent suppression of TFF1, 2 and 3 mRNA expression (Fig. 5b) with a statistically significant inhibition starting at $1 \mathrm{nM}$ DON for TFF1 and TFF2 (i.e., $27 \pm 2$ and $39 \pm 1 \%$ of inhibition, respectively, 
$p<0.05)$ and a nearly total inhibition of the expression of TFF1, 2 and 3 at doses of DON superior or equal to $1 \mu \mathrm{M}$. Determination of $\mathrm{IC}_{50}$ demonstrated that DON was able to inhibit TFFs mRNA expression at very low doses, with $\mathrm{IC}_{50}$ values of $0.042 \pm 0.019,0.056 \pm 0.024$ and $0.372 \pm 0.122 \mu \mathrm{M}$ for TFF1, TFF2 and TFF3, respectively.

In order not to restrict the observation to an intestinal cell line, experiments were also performed on whole intestinal tissues using porcine explants, a well-characterized model to study the effect of mycotoxins (Pierron et al. 2016a; Alassane-Kpembi et al. 2017). Porcine intestinal explants were exposed for 8 or $12 \mathrm{~h}$ to $10 \mu \mathrm{M}$ of DON before analysis of

TFFs mRNA expression (Fig. 6). At 8-h exposure, DON had different effects on TFF1, 2 and 3. Whereas DON inhibited TFF2 and TFF3 expression ( $39 \pm 9$ and $44 \pm 5 \%$ of inhibition, respectively), it caused a stimulation of TFF1 expression (169 $\pm 58 \%$ of increase, $p<0.05$ ). At 12-h exposure, DON inhibited the expression of all TFFs with $53 \pm 10,67 \pm 7$ and $73 \pm 6 \%$ of inhibition for TFF1, TFF2 and TFF3, respectively $(p<0.01)$.

Inhibition of the expression of TFFs by DON relies on the activation of PKR and the MAP kinase p38 and ERK1/2 in HT29-16E cells

DON is known to affect gene expression and cell functions through the initial activation of Protein Kinase $\mathrm{R}$ (PKR) and subsequent activation mitogen-activated protein kinases (MAP kinases) (mainly p38 and ERK1/2) pathways (Maresca 2013; Payros et al. 2016). Specific inhibitors of these pathways were used to evaluate their role in the inhibitory action of DON on TFFs expression in HT29-16E cells (Fig. 7). Results showed that adenine (a specific PKR inhibitor, $2 \mathrm{mM}$ ) abolished the inhibitory effect of DON on TFFs expression ( $120 \pm 39,96 \pm 45,79 \pm 19 \%$ inhibition of DON effect for TFF1, 2 and 3, respectively, $p<0.01$ ). Similarly, SB 203580 (a specific p38 inhibitor, $20 \mu \mathrm{M}$ ) counteracted the inhibitory action of DON on TFFs expression, affecting more TFF1 and 2 expression $(93 \pm 10$ and $52 \pm 8 \%$ inhibition of DON effect for TFF1 and 2, respectively, $p<0.01)$ than TFF3 $(23 \pm 6 \%$ inhibition of DON effect on TFF3, $p<0.05$ ). PD 98059 (a specific ERK1/2 inhibitor, $50 \mu \mathrm{M}$ ) was also able to limit the inhibitory action of DON on TFFs expression, affecting more TFF1 and $3(62 \pm 21$ and $73 \pm 15 \%$ inhibition of DON effect on TFF1 and 3, respectively, $p<0.001)$ than TFF2 (38 $\pm 28 \%$ inhibition of DON effect on TFF2, $p<$ 0.05). Taken together, the use of specific inhibitors demonstrated that the suppressive effect of DON on TFFs expression by human goblet cells relies on the activation of PKR and MAP kinases.

\section{Discussion}

DON is known to affect numerous intestinal functions such as barrier function, nutrient absorption and gut immunity in humans and animals (Maresca 2013; Pinton and Oswald 2014; Payros et al. 2016). Whereas the effects of DON on enterocytes is well documented, its effect on other cells forming the intestinal epithelium, including goblet cells, is the less studied. We recently showed, using porcine explants and human goblet cells (i.e., HT29-16E cells), that DON is able to inhibit the expression and secretion by human and porcine goblet cells of mucins through a PKR and MAP kinase-dependent repression of the resistin-like molecule $\beta$ (RELM- $\beta$ ) (Pinton et al. 2015). In the present study, the same ex vivo and in vitro models were used to evaluate the effect of DON on the expression and secretion of another important family of molecules produced by goblet cells, the trefoil factors (TFFs). TFFs play an important role in the gut since they stimulate tissue regeneration/repair (Taupin and Podolsky 2003; Playford et al. 2004; Hoffmann 2005). It has been established that the repair effect of TFFs does rely on their action on cell proliferation/division but rather through their ability to stimulate cell migration that is essential during epithelial restitution (Dignass et al. 1994). Thus, the deficiency in TFFs is associated with an ineffective intestinal repair response after physical or chemical insults (Mashimo et al. 1996; Furuta et al. 2001; Beck et al. 2004). In vivo and ex vivo studies conducted in pigs and mice have demonstrated that intoxication with DON reduces the length of the intestinal villi (Payros et al. 2017; García et al. 2018; Pierron et al. 2018). Although this shortening of the length of the villi could be attributed to an effect of DON on cell division/cell renewal, an effect of DON on cell migration along the crypt-villi axis through an alteration of the secretion of TFFs could not be ruled out.

Our results confirmed that DON dose-dependently sup- presses the secretion of TFF1, TFF2 and TFF3 by human goblet cells. A wound-healing assay confirmed the inhibitory action of DON on TFFs secretion by human intestinal goblet cells. Indeed whereas the conditioned medium obtained from control HT29$16 \mathrm{E}$ cells was able to stimulate cell migration and wound healing, the conditioned medium obtained from HT29-16E cells treated with DON failed at causing it. Measurement of the expression of TFFs mRNA demonstrated that the inhibition of TFFs secretion by DON is associated to a decrease in their expression. Time-dependent study showed that the effect of DON on TFFs mRNA expression is biphasic, with a moderate initial increase (1.6- to 2.4-fold increase at 3-6 $\mathrm{h}$ exposure compared to control) followed by a strong inhibition of their expression after $6 \mathrm{~h}$ of exposure, with around $50 \%$ 
inhibition after 24-h exposure and almost complete inhibition after 48-h exposure (Fig. 5a) in accordance with the data obtained when measuring the secretion of TFFs at that time. Dose-dependent study of the effect of DON on the expression of TFFs mRNA after 48-h exposure (Fig. 5b) confirmed the results of ELISA and a complete suppression of TFFs mRNA expression by HT29-16E cells exposed to doses of DON superior or equal to $1 \mu \mathrm{M}$. Importantly, ex vivo experiments performed on intestinal explants isolated from pigs confirmed in vitro data obtained with HT29-16E cells, demonstrating the high predictive value of these cells as model of intestinal goblet cells. Interestingly, a recent in vivo study addressed the pre- ventive effect of Lactobacillus rhamnosus on the gut bar- rier defect caused by a mixture of DON and zearalenone in mice (Wan et al. 2016). Although it was not the focus of this study, the authors found that the mixture of DON and ZEA was able to decrease the expression of TFF3 mRNA. This result obtained in vivo with mice confirm our ex vivo and in vitro observations, suggesting that DON effect on TFFs is not species-dependent and is observed at least in mice, pigs and with human goblet cells.

In accordance with previous work (Pinton et al. 2015), measurement of the effect of DON on the viability of HT29-16E cells using LDH and MTT assays gave $I_{50}$ values on cell viability of $79 \pm 27$ and $88 \pm 12$ $\mu \mathrm{M}$, respectively. The fact that modulation of the expression and secretion of TFFs by human goblet cells are observed at sub-toxic doses of DON demonstrated that such effect is independent of general cytotoxicity but rather depends on subtle altera- tions of signal pathways and gene expression in goblet cells. Although DON is known to activate various signal pathways after its initial binding to ribosomes, the major ones are the Protein Kinase R (PKR) and the mitogen-activated protein kinases (MAP kinases) including p38 and ERK1/2 (Maresca 2013). The respective involvement of these pathways in DON signaling and DON effects on intestinal cells depends of the cell type and function affected. For example, the effect of DON on intestinal tight junctions is dependent on p38 and ERK1/2 (Pinton et al. 2010). DON's effect on interleukin 8 secretion by enterocytes (Maresca et al. 2008) and on mucin expression by HT29-16E cells (Pinton et al. 2015) relies on the activation of p38 but not ERK1/2, whereas DON's effect on the invasion of enterocytes by Salmonella depends on ERK1/2 but not p38 (Vandenbroucke et al. 2009). The use of specific inhibitors allowed us to demonstrate that the effect of DON on the expression of TFFs by human goblet cells relies on the activation of PKR and the MAP kinase p38 and ERK1/2. How PKR and/or MAP kinases regulate TFFs expression is presently unknown, further work being necessary to address this question. Nevertheless, our results demonstrate that, although the effects of DON on entero- cytes were mostly studied and described, goblet cells are another important target of DON in the gut. Thus, DON not only affects the ability of goblet cells to produce mucins forming the intestinal mucous layer involved in physical/ chemical protection of the gut and providing board and lodging to the microbiota (Kim and Ho 2010; Pinton et al. 2015), but also affects their ability to produce trefoil factors that are involved in tissue repair and gut immunity/inflammation (Kim and Ho 2010). Interestingly, looking at other important proteins of goblet cells, we also found that DON at doses superior or equal to $1 \mu \mathrm{M}$ is able to strongly suppress the expression of another important protein produced by goblet cells, i.e., the Fc-Y-binding protein or IgG Fc-binding pro- tein (Fcgbp) (unpublished data), a protein of $596 \mathrm{kDa}$ able to covalently bind to mucins, to cross link and stabilize the mucin network (Kim and Ho 2010).

Determination of mycotoxin exposure in humans in Europe has shown that adults may be exposed daily to up to $0.52 \mu \mathrm{g}$ of DON per kg of body weight (Gerding et al. 2014), higher exposure being reported by the Joint FAO/ WHO Expert Committee on Food Additives (JECFA) (up to $2.4 \mu \mathrm{g} / \mathrm{kg}$ of BW per day). Modified forms of DON, such as 3- or 15-acetyl-DON and DON-3 glucoside, potentially fur- ther increase the daily exposure of humans to DON (Berthiller et al. 2013; Ajandouz et al. 2016; Pierron et al. 2016b). The actual provisional maximum tolerable daily intake (PMTDI) and maximal exposure levels found in human food lead to potential intestinal concentrations of 210 and $504 \mathrm{nM}$ of DON, respectively (Maresca and Fantini 2010; Maresca 2013). The fact that alterations of TFFs expression and secretion are observed at $1 \mu \mathrm{M}$ or less of DON is thus alarming. Indeed, due to the important role played by TFFs in intestinal repair, a depletion of TFFs caused by DON may participate in the alterations of the intestinal epi- thelium observed after exposure of humans and animals to this mycotoxin.

Funding information: This work was supported by the Centre National de la Recherche Scientifique (CNRS), the Institut National de la Recherche Agronomique (INRA), the Ministère de l'Enseignement Supérieur et de la Recherche Scientifique and the ANR grants CaDON (ANR-15-CE21) and ExpoMycoPig (ANR-17-Carn012)

Acknowledgments: We would like to thanks Prof Christian Laboisse and Dr Chantal Bou-Hanna that generously give us the HT29-16E cells. We would like also to thanks Dr Elise Courvoisier-Dezord in charge of the maintenance of the GPCR system at the AVB platform (iSm2, Marseille) and Anne Marie Cossalter (INRA, Toxalim, Toulouse) in charge of the animals. 
Conflict of interest statement: The authors declare no conflict of interest.

\section{References}

Aamann L, Vestergaard EM, Gronbaek H (2014) Trefoil factors in inflammatory bowel disease. World J Gastroenterol 20:3223-3230. doi: 10.3748/wjg.v20.i12.3223

Ajandouz EH, Berdah S, Moutardier V, et al (2016) Hydrolytic Fate of 3/15-Acetyldeoxynivalenol in Humans: Specific Deacetylation by the Small Intestine and Liver Revealed Using in Vitro and ex Vivo Approaches. Toxins (Basel) 8:232. doi: 10.3390/toxins8080232

Alassane-Kpembi I, Puel O, Pinton P, et al (2017) Co-exposure to low doses of the food contaminants Deoxynivalenol and Nivalenol has a synergistic inflammatory effect on intestinal explants. Arch Toxicol 91:2677-2687. doi: 10.1007/s00204-016-1902-9

Beck PL, Wong JF, Li Y, et al (2004) Chemotherapy- and radiotherapy-induced intestinal damage is regulated by intestinal trefoil factor. Gastroenterology 126:796-808. doi: 10.1053/j.gastro.2003.12. 004

Bennett JW, Klich M, Mycotoxins M (2003) Mycotoxins. Clin Microbiol Rev 16:497-516. doi: 10.1128/ CMR.16.3.497

Berthiller F, Crews C, Dall'asta C, et al (2013) Masked mycotoxins: A review. Mol Nutr Food Res 57:165186. doi: $10.1002 / \mathrm{mnfr} .201100764$

Chaiyarit $P$, Klanrit $P$, Photipakdee $P$, et al (2015) Diagnostic value evaluation of trefoil factors family 3 for the early detection of colorectal cancer. World J Gastroenterol 18:1305-1312. doi: 10.1007/s00784-013-1094-0

Dellafiora L, Dall'Asta C, Galaverna G (2018) Toxicodynamics of Mycotoxins in the Framework of Food Risk Assessment An In Silico Perspective. Toxins 10:52. doi: 10.3390/toxins10020052

Dignass A, Lynch-Devaney K, Kindon $\mathrm{H}$, et al (1994) Trefoil peptides promote epithelial migration through a transforming growth factor beta-independent pathway. J Clin Invest 94:376-383. doi: $10.1172 / \mathrm{JCl} 117332$

Furuta GT, Turner JR, Taylor CT, et al (2001) Hypoxia-inducible factor 1-dependent induction of intestinal trefoil factor protects barrier function during hypoxia. J Exp Med 193:1027-1034. doi: 10.1084/jem.193.9.1027

García GRGR, Payros D, Pinton P, et al (2018) Intestinal toxicity of deoxynivalenol is limited by Lactobacillus rhamnosus RC007 in pig jejunum explants. Arch Toxicol 92:983-993. doi: 10.1007/s00204-017-2083-X

Gerding J, Cramer B, Humpf HU (2014) Determination of mycotoxin exposure in Germany using an LCMS/MS multibiomarker approach. Mol Nutr Food Res 58:2358-2368. doi: 10.1002/mnfr.2014 00406

Gourbeyre P, Berri M, Lippi Y, et al (2015) Pattern recognition receptors in the gut: analysis of their expression along the intestinal tract and the crypt/villus axis. Physiol Rep 13 e12225: doi: $10.14814 /$ phy2.12225

Graziani F, Pujol A, Nicoletti C, et al (2015) The Food-Associated Ribotoxin Deoxynivalenol Modulates Inducible NO Synthase in Human Intestinal Cell Model. Toxicol Sci 145:372-382. doi: 10.1093/ toxsci/kfv058

Hoffmann W (2005) Trefoil factors TFF (trefoil factor family) peptide-triggered signals promoting mucosal restitution. Cell Mol Life Sci 62:2932-2938. doi: 10.1007/s00018-005-5481-9

Hoffmann W (2009) Trefoil factor family (TFF) peptides and chemokine receptors: a promising relationship. J Med Chem 52:6505-6510. doi: 10.1021/jm9008136

Kim YS, Ho SB (2010) Intestinal goblet cells and mucins in health and disease: recent insights and progress. Curr Gastroenterol Rep 12:319-330. doi: 10.1007/s11894-010-0131-2

Kjellev S (2009) The trefoil factor family - small peptides with multiple functionalities. Cell Mol Life Sci 66:1350-1369. doi: 10.1007/s00018-008-8646-5

Livak KJ, Schmittgen TD (2001) Analysis of relative gene expression data using real-time quantitative PCR and the 2(-Delta Delta C(T)) Method. Methods 25:402-408. doi: 10.1006/meth.2001.1262

Lucioli J, Pinton P, Callu P, et al (2013) The food contaminant deoxynivalenol activates the mitogen activated protein kinases in the intestine: Interest of ex vivo models as an alternative to in vivo experiments. Toxicon 66:31-36. doi: 10.1016/j.toxicon.2013.01.024

Madsen J, Nielsen O, Tornoe I, et al (2007) Tissue localization of human trefoil factors 1, 2, and 3. J Histochem Cytochem 55:505-513. doi: 10.1369/jhc.6A7100.2007

Maresca M (2013) From the gut to the brain: Journey and pathophysiological effects of the foodassociated trichothecene mycotoxin deoxynivalenol. Toxins 5:784-820. doi: 10.3390/toxins 50407 84

Maresca M, Fantini J (2010) Some food-associated mycotoxins as potential risk factors in humans predisposed to chronic intestinal inflammatory diseases. Toxicon 56:282-294. doi: 10.1016/ 
j.toxicon.2010.04.016

Maresca M, Yahi N, Younes-Sakr L, et al (2008) Both direct and indirect effects account for the proinflammatory activity of enteropathogenic mycotoxins on the human intestinal epithelium: Stimulation of interleukin-8 secretion, potentiation of interleukin-1beta effect and increase in the transepithel. Toxicol Appl Pharmacol 228:84-92. doi: 10.1016/j.taap.2007.11.013

Mashimo H, Wu DC, Podolsky DK, Fishman MC (1996) Impaired defense of intestinal mucosa in mice lacking intestinal trefoil factor. Science 274:262-265. doi: 10.1126/science.274.5285.262

Payros D, Alassane-Kpembi I, Pierron A, et al (2016) Toxicology of deoxynivalenol and its acetylated and modified forms. Arch Toxicol 12:2931-2957. doi: 10.1007/s00204-016-1826-4

Payros D, Dobrindt U, Martin P, et al (2017) The food contaminant deoxynivalenol exacerbates the genotoxicity of gut microbiota. MBio 8: e00007-17. doi: 10.1128/mBio.00007-17

Pestka JJ (2010) Deoxynivalenol: Mechanisms of action, human exposure, and toxicological relevance. Arch Toxicol 84:663-679. doi: 10.1007/s00204-010-0579-8

Pierron A, Bracarense APFL, Cossalter AM, et al (2018) Deepoxy-deoxynivalenol retains some immunemodulatory properties of the parent molecule deoxynivalenol in piglets. Arch Toxicol 92:3381-3389. doi: 10.1007/s00204-018-2293-x

Pierron A, Mimoun S, Murate LS, et al (2016a) Microbial biotransformation of DON: molecular basis for reduced toxicity. Sci Rep 6:29105. doi: 10.1038/srep29105

Pierron A, Mimoun S, Murate LS, et al (2016b) Intestinal toxicity of the masked mycotoxin deoxynivalenol-3-beta-D-glucoside. Arch Toxicol 90:2037-2046. doi: 10.1007/s00204-015-1592-8

Pinton P, Braicu C, Nougayrede J-PP, et al (2010) Deoxynivalenol Impairs Porcine Intestinal Barrier Function and Decreases the Protein Expression of Claudin-4 through a Mitogen-Activated Protein Kinase-Dependent Mechanism. J Nutr 140:1956-1962. doi: 10.3945/jn.110.123919

Pinton P, Graziani F, Pujol A, et al (2015) Deoxynivalenol inhibits the expression by goblet cells of intestinal mucins through a PKR and MAP kinase-dependent repression of the resistin-like molecule beta. Mol Nutr Food Res 59:1076-1087. doi: 10.1002/mnfr.201500005

Pinton P, Oswald IPP (2014) Effect of deoxynivalenol and other Type B trichothecenes on the intestine: a review. Toxins (Basel) 6:1615-1643. doi: 10.3390/toxins6051615

Pinton P, Tsybulskyy D, Lucioli J, et al (2012) Toxicity of deoxynivalenol and its acetylated derivatives on the intestine: Differential effects on morphology, barrier function, tight junction proteins, and mitogen-activated protein kinases. Toxicol Sci 130: 180-190. doi: 10.1093/toxsci/kfs239

Playford RJ, Ghosh S, Mahmood A (2004) Growth factors and trefoil peptides in gastrointestinal health and disease. Curr Opin Pharmacol 4:567-571. doi: 10.1016/j.coph.2004.05.004

Potten CS, Kellett M, Roberts SA, et al (1992) Measurement of in vivo proliferation in human colorectal mucosa using bromodeoxyuridine. Gut 33:71-78. doi: 10.1136/gut.33.1.71

Razafimanjato H, Benzaria A, Taieb N, et al (2011) The ribotoxin deoxynivalenol affects the viability and functions of glial cells. Glia 59:1672-1683. doi: 10.1002/glia.21214

Razafimanjato H, Garmy N, Guo X-J, et al (2010) The food-associated fungal neurotoxin ochratoxin A inhibits the absorption of glutamate by astrocytes through a decrease in cell surface expression of the excitatory amino-acid transporters GLAST and GLT-1. Neurotoxicology 31:475-484. doi: 10.1016/j.neuro.2010.06.003

Robert H, Payros D, Pinton P, et al (2017) Impact of mycotoxins on the intestine: are mucus and microbiota new targets? Crit Rev Toxicol 20:249-275. doi: 10.1080/10937404.2017.1326071

Sturm A, Dignass AU (2008) Epithelial restitution and wound healing in inflammatory bowel disease. World J Gastroenterol 14:348-353. doi: 10.3748/wjg.14.348

Taupin D, Podolsky DK (2003) Trefoil factors: initiators of mucosal healing. Nat Rev Mol Cell Biol 4:721732. doi: $10.1038 / \mathrm{nrm} 1203$

Vandenbroucke V, Croubels S, Verbrugghe E, et al (2009) The mycotoxin deoxynivalenol promotes uptake of Salmonella Typhimurium in porcine macrophages, associated with ERK1/2 induced cytoskeleton reorganization. Vet Res 40:64. doi: 10.1051/vetres/2009045

Wan MLY, Turner PC, Allen KJ, El-Nezami H (2016) Lactobacillus rhamnosus GG modulates intestinal mucosal barrier and inflammation in mice following combined dietary exposure to deoxynivalenol and zearalenone. J Funct Foods 22:34-43. doi: 10.1016/j.jf.2016.01.014

Wu F, Groopman JD, Pestka JJ (2014) Public health impacts of foodborne mycotoxins. Annu Rev Food Sci Technol 5:351-372. doi: 10.1146/annurev-food-030713-092431

Xiao P, Ling H, Lan G, et al (2015) Trefoil factors: Gastrointestinal-specific proteins associated with gastric cancer. Clin Chim Acta 450:127-134. doi: 10.1016/j.cca.2015.08.004

Xie H, Guo J-H, An W-M, et al (2017) Diagnostic value evaluation of trefoil factors family 3 for the early detection of colorectal cancer. World J Gastroenterol 23:2159-2167. doi: 10.3748/wjg.v23.i12.2159 
Table 1: Sequences of primers used in this study for human mRNA analysis.

\begin{tabular}{|c|c|c|c|c|c|c|c|}
\hline Gene & Accession & Description & Amplicon & Primers & Length & $\mathrm{Tm}$ & $\% G C$ \\
\hline \multirow{2}{*}{ GAPDH } & \multirow{2}{*}{ NM_002046.3 } & \multirow{2}{*}{$\begin{array}{l}\text { Glyceraldehyde- } \\
\text { 3-phosphate } \\
\text { dehydrogenase }\end{array}$} & \multirow{2}{*}{$119 \mathrm{nt}$} & gagtccactggcgtcttcac & 20 & 60 & 60 \\
\hline & & & & ttcacacccatgacgaacat & 20 & 59 & 45 \\
\hline \multirow{2}{*}{ TFF1 } & \multirow{2}{*}{ NM_003225.2 } & \multirow{2}{*}{ Trefoil factor 1} & \multirow{2}{*}{$78 \mathrm{nt}$} & cccctggtgcttctatccta & 20 & 59 & 55 \\
\hline & & & & gatccctgcagaagtgtctaaaa & 23 & 59 & 43 \\
\hline \multirow{2}{*}{ TFF2 } & \multirow{2}{*}{ NM_005423.4 } & \multirow{2}{*}{ Trefoil factor 2} & \multirow{2}{*}{$109 \mathrm{nt}$} & Ggaagtgctgcttctccaac & 20 & 59 & 55 \\
\hline & & & & Ccagatgcatcctctggaac & 20 & 60 & 55 \\
\hline \multirow{2}{*}{ TFF3 } & \multirow{2}{*}{ NM_003226.3 } & \multirow{2}{*}{ Trefoil factor 3} & \multirow{2}{*}{$87 \mathrm{nt}$} & Gctgctgctttgactccag & 19 & 59 & 58 \\
\hline & & & & Tggaggtgcctcagaaggt & 19 & 60 & 58 \\
\hline
\end{tabular}

Table 2: Sequences of primers used in this study for porcine mRNA analysis.

\begin{tabular}{|c|c|c|c|c|c|c|c|}
\hline Gene & Accession & Description & $\begin{array}{l}\text { Amplic } \\
\text { on }\end{array}$ & Primers & $\begin{array}{c}\text { Lengt } \\
\mathrm{h}\end{array}$ & $\begin{array}{l}\mathbf{T} \\
\mathbf{m} \\
\end{array}$ & $\begin{array}{c}\% G \\
C\end{array}$ \\
\hline \multirow{2}{*}{ TFF1 } & \multirow{2}{*}{ AM283538.1 } & \multirow{2}{*}{$\begin{array}{l}\text { Sus scrofa } \\
\text { Trefoil factor } \\
1\end{array}$} & \multirow{2}{*}{$68 \mathrm{nt}$} & tgccagagtgaactgtggtttc & 22 & 59 & 50 \\
\hline & & & & caaagcagcagcctttttttc & 22 & 59 & 41 \\
\hline \multirow{2}{*}{ TFF2 } & \multirow{2}{*}{$\begin{array}{l}\text { XM_003358971. } \\
1\end{array}$} & \multirow{2}{*}{$\begin{array}{l}\text { Sus scrofa } \\
\text { Trefoil factor } \\
2\end{array}$} & \multirow{2}{*}{$110 \mathrm{nt}$} & atcaccagcgaccagtgctt & 20 & 59 & 55 \\
\hline & & & & $\begin{array}{l}\text { atgacgcactcctcagactctt } \\
\text { g }\end{array}$ & 23 & 60 & 52 \\
\hline \multirow{2}{*}{ TFF3 } & \multirow{2}{*}{$\begin{array}{l}\text { NM_001243483. } \\
1\end{array}$} & \multirow{2}{*}{$\begin{array}{l}\text { Sus scrofa } \\
\text { Trefoil factor } \\
3\end{array}$} & \multirow{2}{*}{$118 \mathrm{nt}$} & caggatgttctggctgctagtg & 22 & 59 & 54 \\
\hline & & & & gcagtccaccctgtccttg & 19 & 58 & 63 \\
\hline \multirow{2}{*}{$\begin{array}{l}\text { Cyclophili } \\
\text { n }\end{array}$} & \multirow{2}{*}{ NM_214353 } & \multirow{2}{*}{$\begin{array}{l}\text { peptidylprolyl } \\
\text { isomerase A }\end{array}$} & \multirow{2}{*}{$92 \mathrm{nt}$} & cccaccgtcttcttcgacat & 20 & 62 & 55 \\
\hline & & & & tctgctgtctttggaactttgtct & 24 & 68 & 41 \\
\hline \multirow{2}{*}{ B2M } & \multirow{2}{*}{ NM_213978 } & \multirow{2}{*}{$\begin{array}{l}\text { beta-2- } \\
\text { microglobulin }\end{array}$} & \multirow{2}{*}{$162 \mathrm{nt}$} & ttctaccttctggtccacactga & 23 & 68 & 48 \\
\hline & & & & tcatccaacccagatgca & 18 & 54 & 50 \\
\hline \multirow{2}{*}{ RPL 32} & \multirow{2}{*}{ NM_001001636 } & \multirow{2}{*}{$\begin{array}{l}\text { ribosomal } \\
\text { protein L32 }\end{array}$} & \multirow{2}{*}{$92 \mathrm{nt}$} & agttcatccggcaccagtca & 20 & 62 & 55 \\
\hline & & & & gaaccttctccgcaccctgt & 20 & 64 & 60 \\
\hline
\end{tabular}

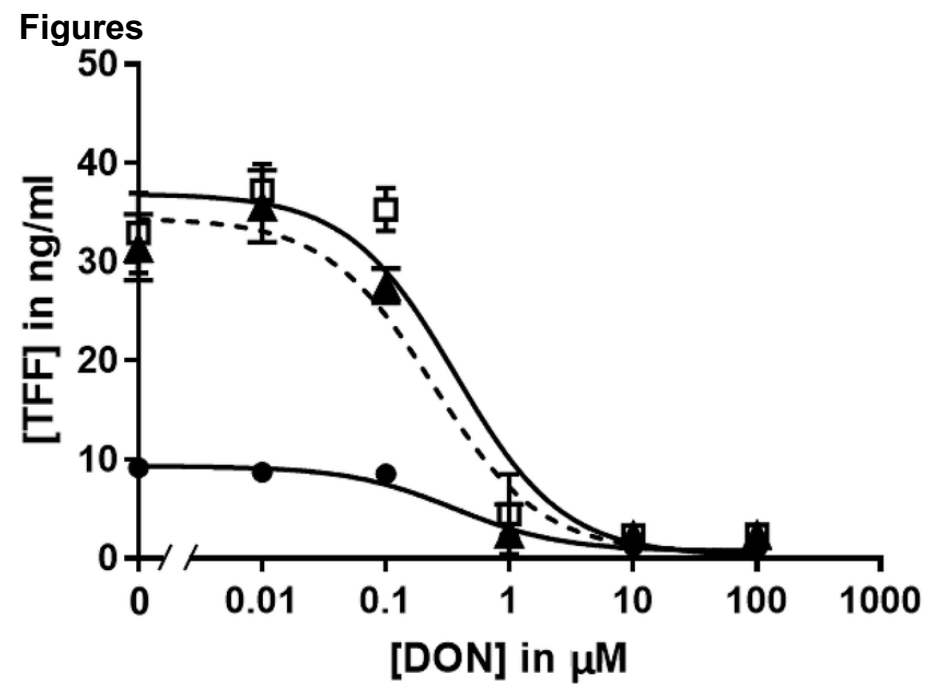

Figure 1: DON dose-dependently inhibits the secretion of TFFs by human goblet cells.

HT29-16E cells were exposed for $48 \mathrm{~h}$ to increasing doses of DON and the secretion of TFF1, 2 and 3 in the culture supernatant was measured. Results were expressed as means \pm SD. 

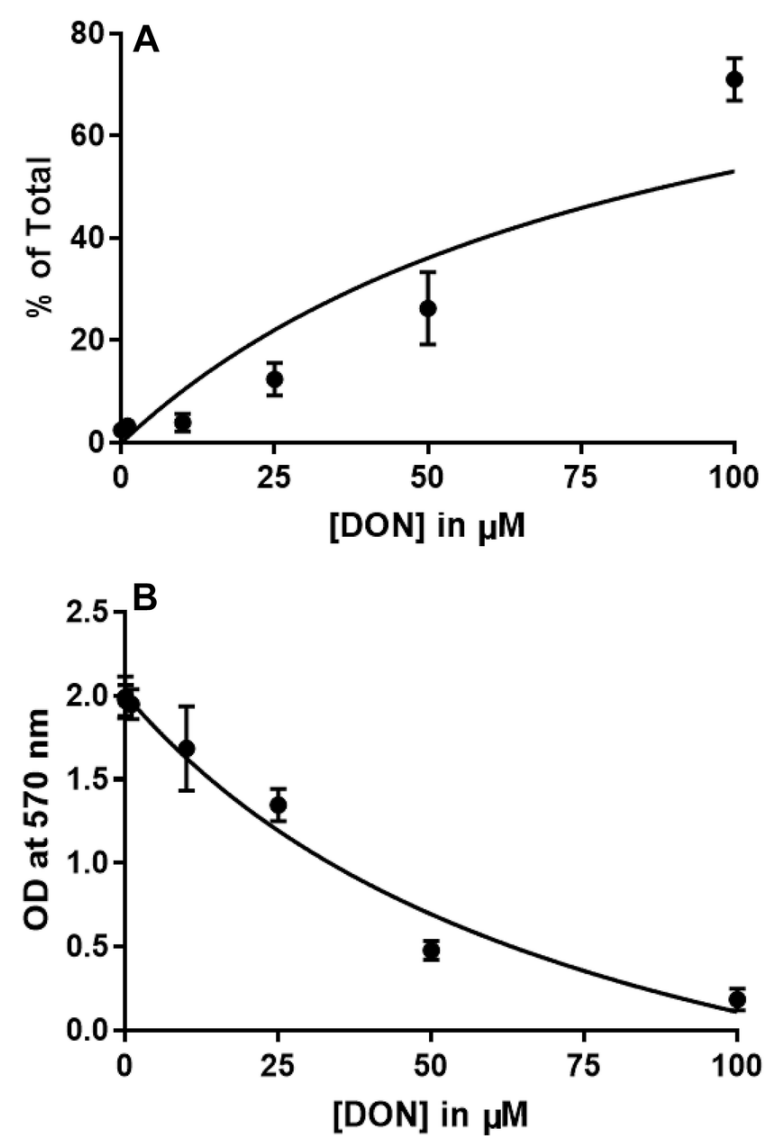

Figure 2: Evaluation of the toxicity of DON on human goblet cells using the LDH and MTT assays. HT29-16E cells were exposed for $48 \mathrm{~h}$ to increasing doses of DON and the cell viability and integrity were measured by the LDH (A) and the MTT (B) assays, as explained in Materials and Methods. Results were expressed as means $\pm S D$, with ${ }^{*} p$ at least $<0.05(n=3)$. 
T0

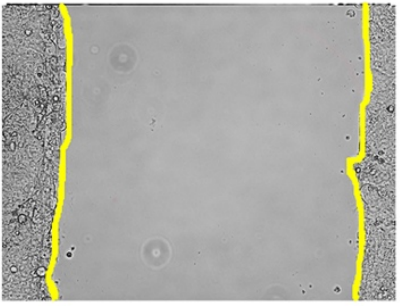

DMEM+FCS (positive control)

DMEM-FCS (negative control)

HT29-16E - DON conditioned medium (DMEM - FCS)

\section{HT29-16E + DON conditioned medium (DMEM - FCS)}
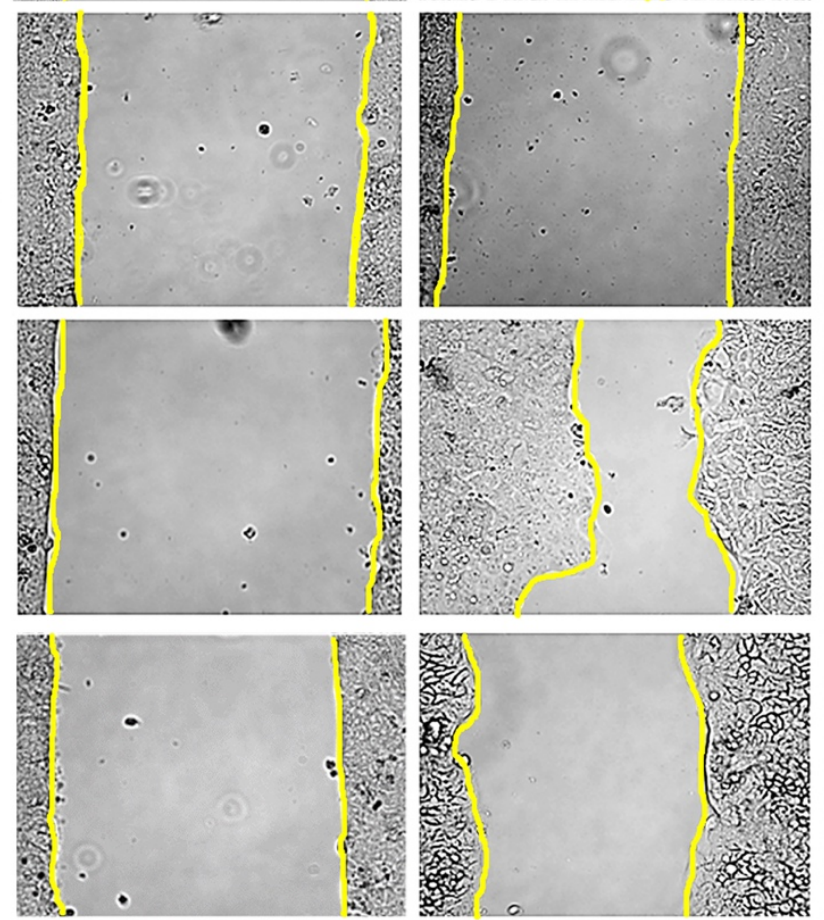

T48h
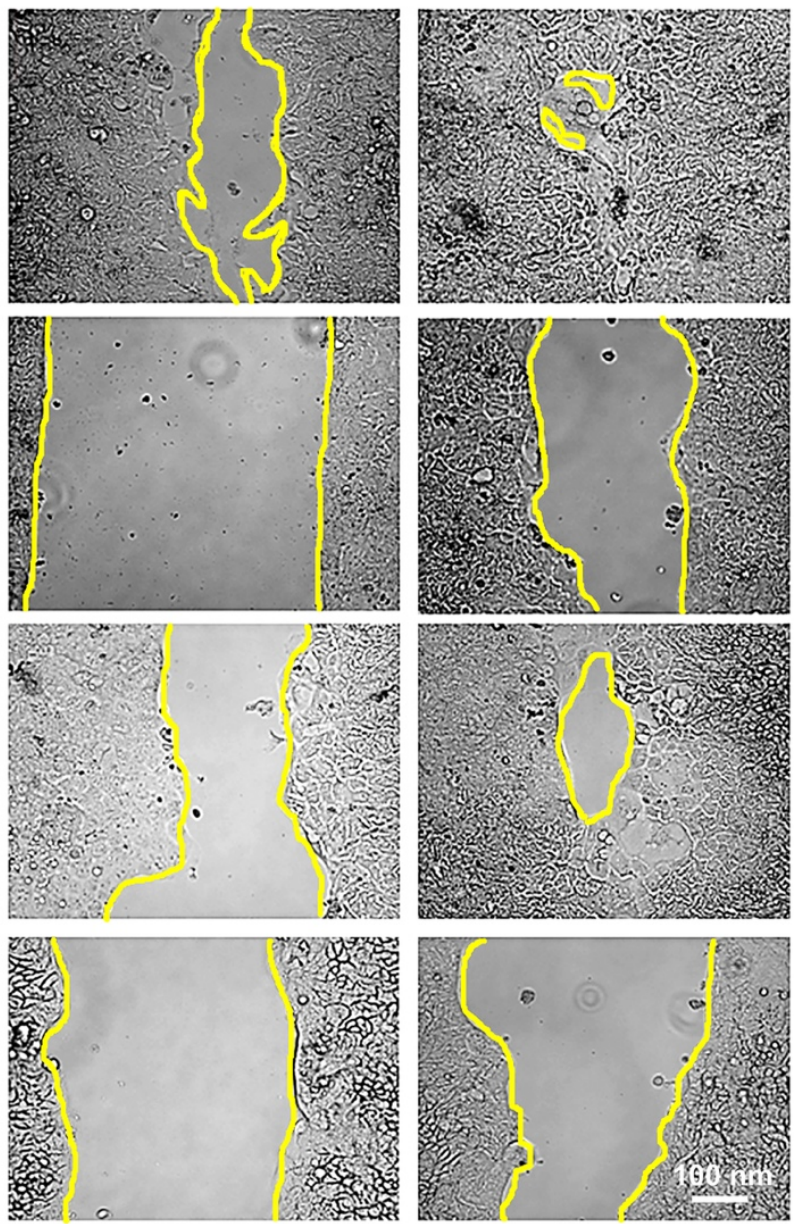

Figure 3: DON suppresses the wound healing capacity of the supernatant of HT29-16E cells. Wound healing assay was performed using Caco-2 cells and conditioned medium from HT29-16E cells treated or not with DON $(10 \mu \mathrm{M}, 48 \mathrm{~h})$ as explained in Materials and Methods. Wound closure was observed and pictures were taken after 0 (T0), $24 \mathrm{~h}$ (T24h) and $48 \mathrm{~h}$ (T48h) of incubation. For better observation of the healing, limits of the wound were unde rlined in yellow. Pictures are representative of observations done in triplicate $(n=3)$. White bar represents $100 \mathrm{~nm}$. 

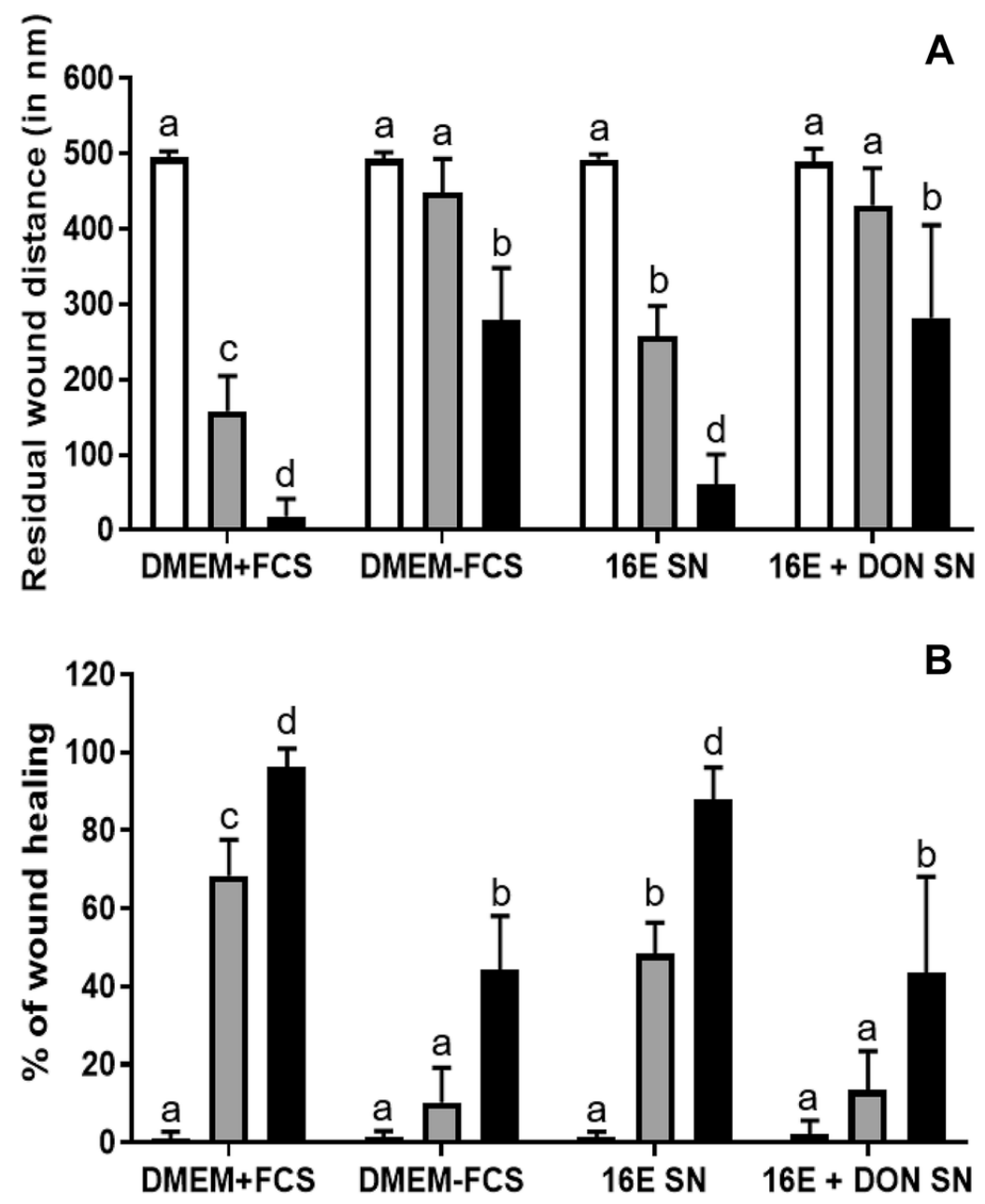

Figure 4: Quantification of the inhibition of the wound healing by DON.

Pictures of Figure 3 were used to measure the wound healing capacity of complete culture medium (DMEM+FCS), culture medium without fetal calf serum (DMEM-FCS), supernatant obtained from untreated HT29-16E cells (16E SN) or supernatant obtained from HT29-16E cells treated with DON 10 $\mu \mathrm{M} 48 \mathrm{~h}(16 \mathrm{E}+\mathrm{DON} \mathrm{SN})$ as explained in Materials and Methods. Wound healing capacity was measured in term of residual wound distance $(\mathbf{A})$ and of percentage of healing $(\mathbf{B})$. Results were expressed as means $\pm \operatorname{SD}(n=3)$. Bars without a common letter differ by at least $p<0.05$. 


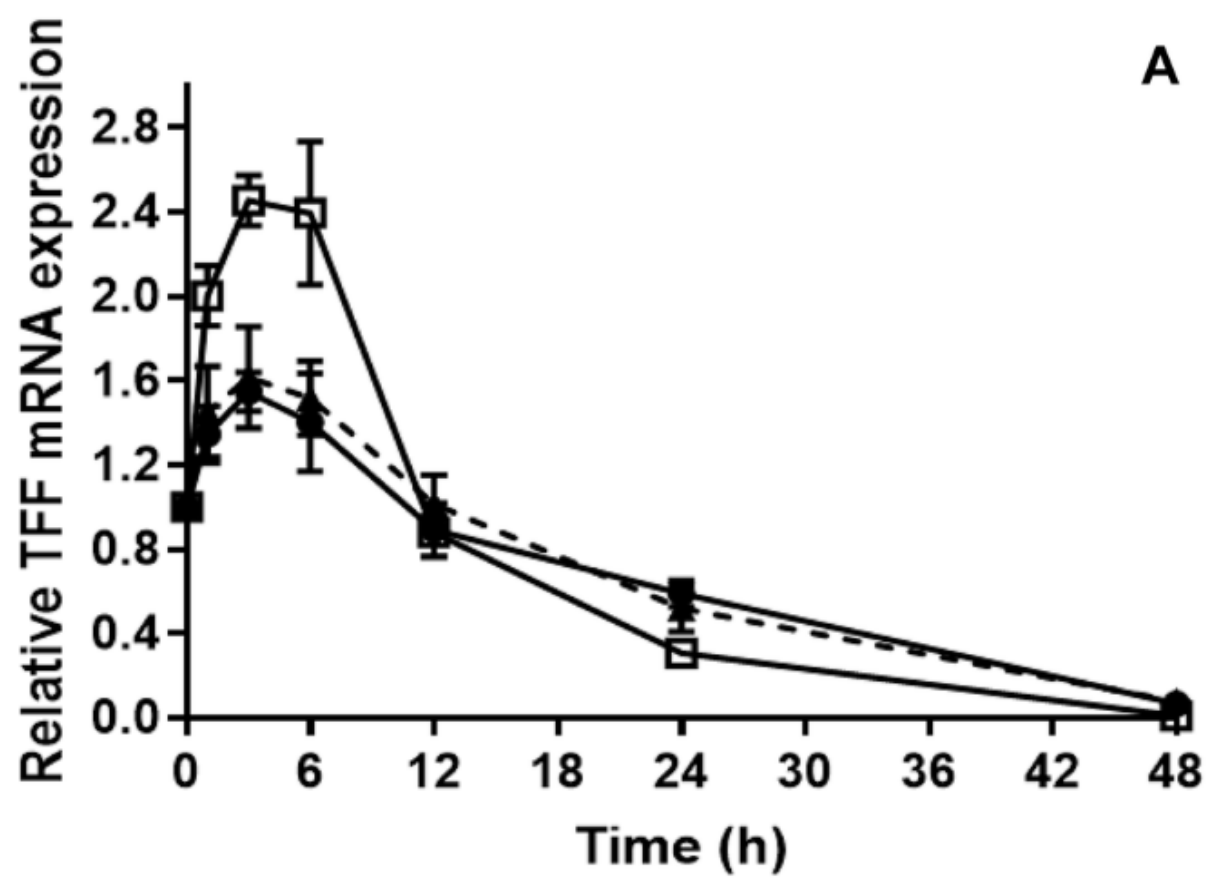

B

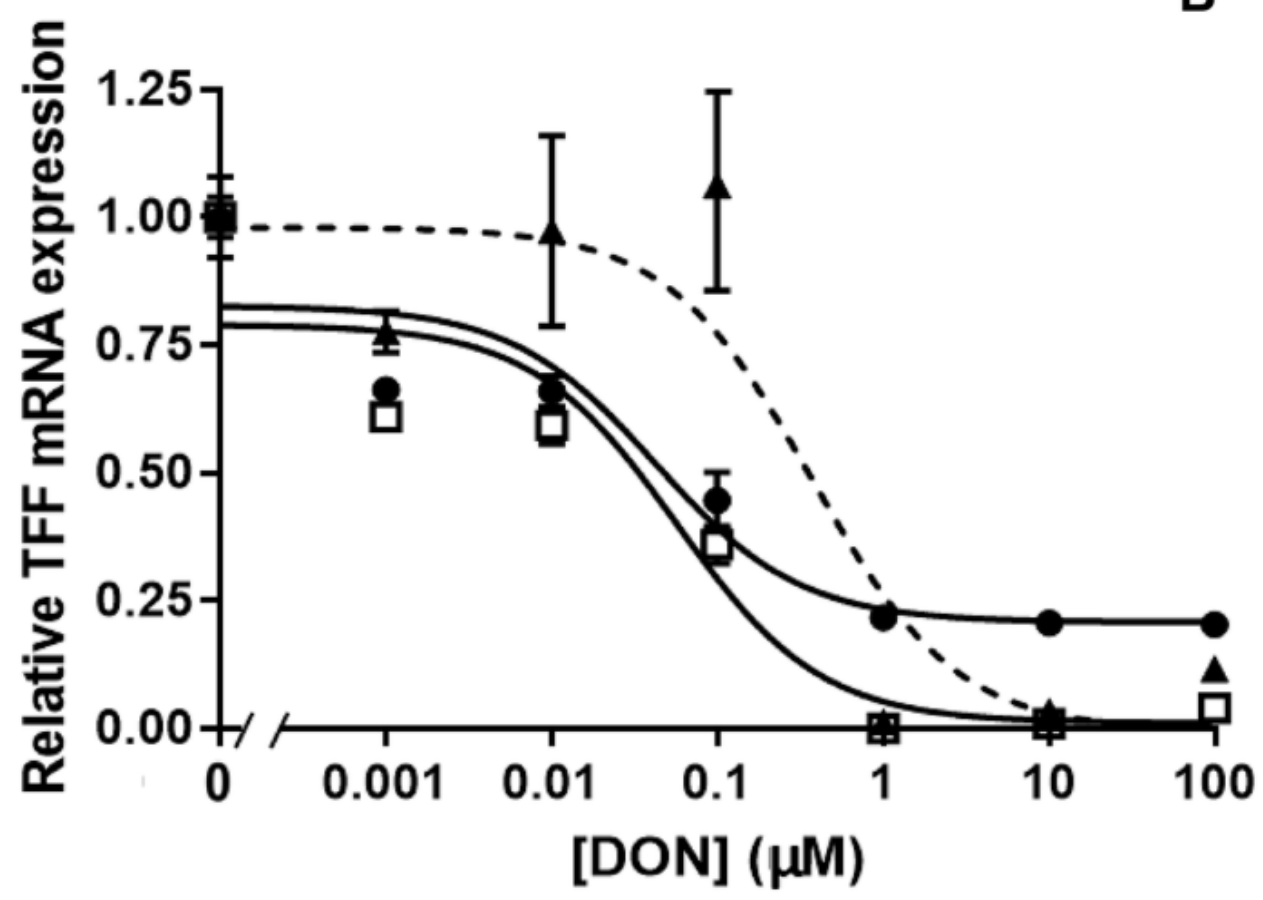

Figure 5: DON inhibits the expression of TFFs mRNA in human goblet cells.

A- HT29-16E cells seeded onto 12-well plate were treated with $10 \mu \mathrm{M}$ of DON for various times. At the end of the incubation, human TFFs mRNA were quantified and normalized against GAPDH mRNA. Results were expressed as fold increase in target mRNA production compared to untreated cells (means $\pm \mathrm{SD})(\mathrm{n}=3)$.

B- HT29-16E cells seeded onto 12-well plate were treated with increasing doses of DON for $48 \mathrm{~h}$. At the end of the incubation, human TFFs mRNA were quantified and normalized against GAPDH mRNA. Results were expressed as fold increase in target mRNA production compared to untreated cells (means $\pm S D)(n=3)$. 


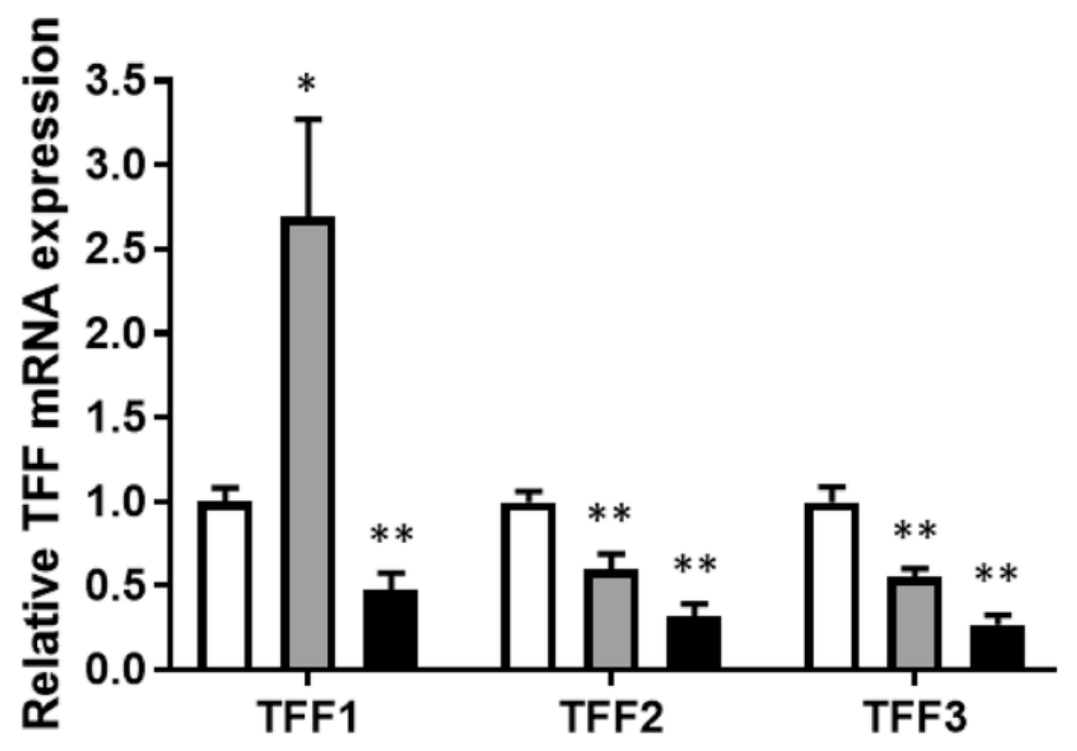

Figure 6: DON time-dependently inhibits the expression of TFFs mRNA in intestinal explants from pigs.

Explants were treated with $10 \mu \mathrm{M}$ of DON for 0,8 or $12 \mathrm{~h}$. At the end of the incubation, porcine TFFs mRNA were quantified and normalized using cyclophilin $A$, ribosomal protein $L 32$ and $\beta$-2micoglobulin mRNA. Results were expressed as fold increase in target mRNA production compared to untreated cells (means \pm SD, with * $p<0.05$ and ${ }^{* *} p<0.01(n=6)$ ).

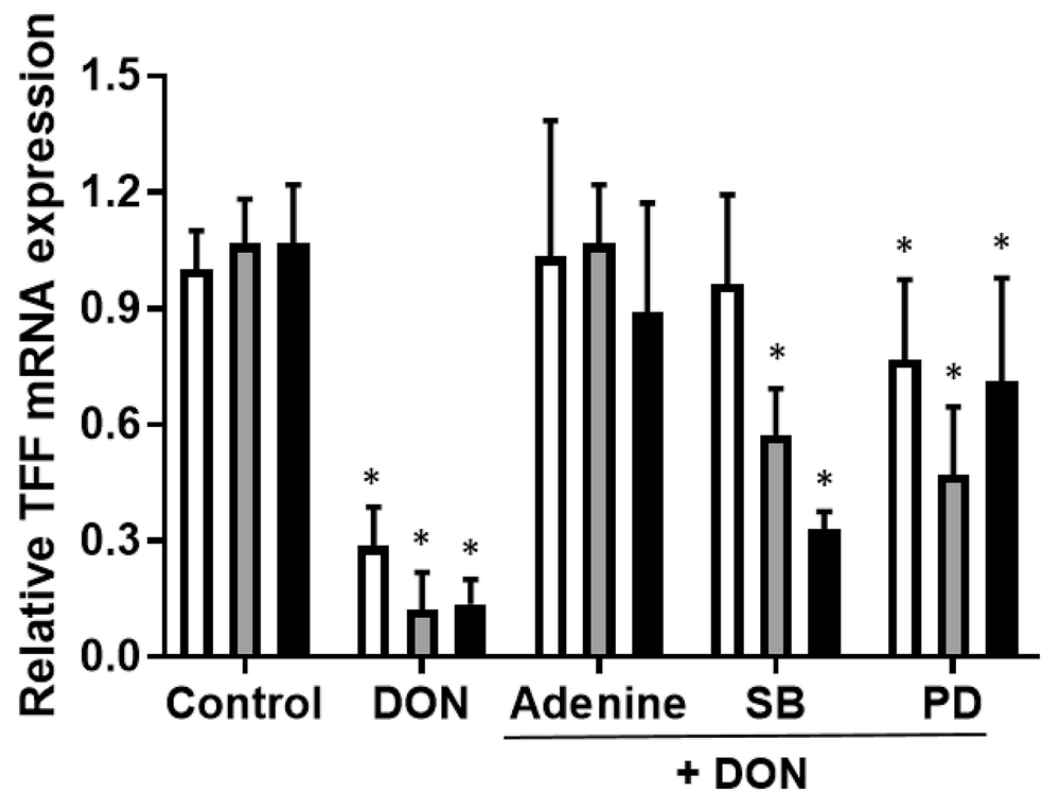

Figure 7: PKR, p38 and ERK1/2 inhibitors prevent the effect of DON on TFFs mRNA expression. HT29-16E cells seeded onto 12-well plate were pre-treated with PKR inhibitor (adenine (Ad) at $2 \mathrm{mM}$ ) or with inhibitors of the MAP kinases p38 (SB 203580 (SB) at $20 \mu \mathrm{M}$ ) or ERK1/2 (PD 98059 (PD) at 50 $\mu \mathrm{M})$. HT29-16E cells were then treated with $10 \mu \mathrm{M}$ of DON for $48 \mathrm{~h}$. At the end of the incubation, TFFs mRNA were quantified and normalized using GAPDH mRNA. Results were expressed as fold increase in target mRNA production compared to untreated cells (means $\pm \mathrm{SD}$, with ${ }^{*} p<0.05,{ }^{* *} p<0.01$ and $\left.{ }^{* * *} p<0.001(\mathrm{n}=3)\right)$. 